\title{
NOTES
}

\section{MARITIME PIRACY IN THE GULF OF GUINEA}

\section{Henrique Portela Guedes}

maildoportela@gmail.com

Portuguese Navy Captain (Portugal), graduated in Naval Military Sciences, by Escola Naval, postgraduate in International Humanitarian Law and Human Rights in conflict situations, by Instituto Europeu/IDN, and in Advanced Geopolitics Studies, for Universidade Autónoma de Lisboa/IDN. He is currently an Advisor and researcher in the Instituto da Defesa Nacional (IDN). He has a vast set of articles published on Maritime Piracy in Portugal, Spain, Brazil and the United Kingdom, is the author of the book 'The World of Maritime Piracy: the last two decades' and co-author of two sub-chapters in the book 'Safety at Sea: A holistic view'.

Maritime piracy dates back to the beginnings of maritime navigation, when the first commercial exchanges by sea began, having been considered practically extinct in the 19 th century.

It began to increase gradually from the end of the 1980s, however, the world only woke up to this reality with the outbreak of maritime piracy in the waters of Somalia in 2008. Since then, to this day, this phenomenon has become a serious threat to global maritime security.

Currently, the Gulf of Guinea (GG) is the major concern of the international community, due to the high number of acts of piracy that have been registered there.

This growth is due to several factors, mostly common to practically all the countries that are part of this Gulf, such as: deficient social policies, high corruption, high demography, high unemployment rates and huge proliferation of criminal networks. These are the factors that, associated with the lack of maritime policies on the part of the States in the region and of naval means to ensure the surveillance of their waters, have caused this area to register an increasing number of pirate attacks and, consequently, be considered as one of the most dangerous in the world for maritime navigation. 


\section{Causes, concerns and mitigation actions}

There are several locations worldwide that are considered hotspots for maritime piracy ${ }^{1}$ and Armed Robbery Against Ships (ARAS) ${ }^{2}$, that is, places that due to different factors have become prone to this type of acts. These locations, situated close to major sea routes, are usually associated with the existence of states with weak or failed governments, where social policies are deficient or non-existent, unemployment rates are very high, poverty levels are extremely high and have a high demographic density, mostly young people. Many of these factors are present, to a greater or lesser extent, in the countries of the GG, which has contributed a lot to the increase in maritime piracy / ARAS in the region, namely in the waters of Nigeria.

The GG region is located ${ }^{3}$ between Côte d'Ivoire and Gabon, and includes, in addition to these countries, Ghana, Togo, Benin, Nigeria, Cameroon, Equatorial Guinea and São Tomé and Príncipe. Geographically, it contains the crossing of the Equator line with the Greenwich meridian.

This Gulf has become, in recent decades, a place of excellence for commercial navigation. This role is closely associated with the huge hydrocarbon deposits in this area and the geographical location of the region (proximity to Europe and the USA).

Despite all this prosperity, this Gulf is currently one of the most dangerous maritime areas in the world, due to the great regional insecurity that is felt there. If this is not overcome in the near future, it could endanger the entire global economic strategy for this region of the globe, especially the one related to the trade of "black gold" and natural gas from Nigeria.

The existence of an increasing number of criminal networks on land, associated with the lack of maritime policies on the part of the states in the region, has led some of these to engage in maritime piracy / ARAS. These rebel groups, mostly from Nigeria, started their activity on the Nigerian coast, however, they gradually extended their area of activity to the waters of Benin, Togo, Ghana, Cameroon, Equatorial Guinea and São Tomé and Príncipe. The increase in maritime piracy / ARAS in this part of Africa is currently a major concern for the international community, because the states in the region are unable to guarantee maritime safety in their waters. The apprehension about this insecurity at sea is denoted even by the African countries themselves, as these attacks are becoming a serious problem for maritime transport, which has been causing a slight decrease in trade in the region and, consequently, a reduction in port revenues, due to the fact that there are fewer ships practicing them.

In recent years, the states of this Gulf have started to develop some maritime policies, because in the last decades their attention has almost always been focused on the control of their territories on the continent, therefore they have not devoted much attention to

Illicit acts of violence and / or detention and / or pillaging committed, for private purposes, by the crew and / or passengers of a private ship, and directed against a ship and / or people and / or goods on board it, committed beyond 12 nautical miles (territorial sea).

2 Illicit acts identical to those of piracy, only committed in the territorial sea or in inland waters. The territorial sea consists of a maritime area, under national sovereignty, that goes up to 12 nautical miles, counted from the "coast line" (straight or normal base line) of a State. One nautical mile is 1852 meters.

3 According to the International Hydrographic Organization. This Gulf is sometimes considered to extend from Senegal to Angola, that is, it is located between the parallels $15^{\circ} 0^{\prime} 0^{\prime \prime} \mathrm{N}$ and $15^{\circ} 0^{\prime} 0^{\prime \prime} \mathrm{S}$. 
their sea. As a result, their naval forces are poorly equipped, poorly trained and underfunded to be able to secure state authority at sea in their waters.

The increase in maritime piracy / ARAS in the GG has led the UN to monitor this situation regularly, and with great concern. Proof of this is the approval by its Security Council of two Resolutions related to this theme, Resolution 2018 (2011), of October 31, and Resolution 2039 (2012), of February 29. These included the need for concerted action by countries in the region to deal with maritime piracy / ARAS, through the development of a comprehensive and structured regional strategy, which includes the exchange of information and the development of operational coordination mechanisms.

The various subregional organizations have since been very available to help combat the various types of illegal activities in the region. The Economic Community of Central African States ${ }^{4}$ (ECCAS) has collaborated with the states of this Gulf in implementing a maritime security strategy, which includes support for their navies and assistance in organizing joint exercises in order to fight the insecurity in the GG region.

On the other hand, the Economic Community of West African States ${ }^{5}$ (ECOWAS) has also been interested in collaborating. Good cooperation between ECCAS and ECOWAS could allow for joint maritime patrol actions, as well as the right of persecution across maritime borders. The Gulf of Guinea Commission ${ }^{6}$ (GGC) has also remained active in recent years and it is from all these African organizations the one which mandate gives it special openness to be able to deal specifically with maritime issues.

All the collaboration policies that have been adopted in Africa on maritime security are still in an embryonic phase and, if they are not closely monitored by a continuous presence at sea, they will be mere symbolic actions. Some of the Western powers with interests in the region have shown themselves to be available to support these initiatives both financially and with the exchange of knowledge in the area of security. In recent years, countries such as the USA, France and Portugal, among others, have been very attentive to the region's problems and, through cooperation programs, have participated with their ships in joint exercises with the GG navies. The main objective of these is to increase the capacity of these navies to respond to maritime piracy / ARAS or any other type of maritime crime, through the improvement of interoperability of communications, information sharing and training actions within the scope of operational activities related to maritime safety.

Among the various multinational exercises / activities ${ }^{7}$ that take place regularly in West Africa, the OBANGAME EXPRESS exercise, held annually since 2011, inclusive, is the one with the largest number of participating countries / organizations and is sponsored by the USA, through the U.S. Africa Command. In March 2019, it held its 9th edition, which brought together forces from Africa, Europe and South and North America, in a total of

4 It consists of ten member countries: Burundi, Cameroon, the Central African Republic, Chad, Congo, Equatorial Guinea, Gabon, São Tomé and Príncipe, the Democratic Republic of Congo and Angola.

5 The fifteen member countries are: Benin, Burkina Faso, Cape Verde, Côte d'Ivoire, Gambia, Ghana, Guinea, Guinea-Bissau, Liberia, Mali, Niger, Nigeria, Senegal, Sierra Leone and Togo.

6 It consists of eight countries: Angola, Cameroon, Democratic Republic of Congo, Congo, Gabon, Equatorial Guinea, Nigeria and São Tomé and Príncipe.

7 The CORYMBE operation, which has been carried out by France, almost continuously, since 1990, the GRAND AFRICAN NEMO exercise, also led by France, and the OPEN SEA initiative carried out by Portugal. 
31 countries $^{8}$, of which 20 are Africans, with the collaboration of several regional and international organizations, such as ECCAS and ECOWAS, among others.

Despite all these initiatives to fight maritime crime, there are serious doubts regarding its effectiveness and sustainability, because the means will always be few and the criminals will quickly move from the most patrolled areas to the least guarded areas. It is easily anticipated that if there is no involvement of international institutions, with a view to a global maritime security strategy for the region, it is unlikely with single measures that this arduous task of combating maritime piracy / ARAS in GG will be successful.

\section{Nigerian pirates: the protagonists of insecurity}

Nigeria, despite being the country with the largest economy in the region and having the largest armed forces in the GG, is considered by neighboring countries as the focus of this Gulf's problems, much due to the fact that it is unable to stabilize its region of the Niger River Delta ${ }^{9}$, densely populated area and from which it derives most of the oil exploited on land. The Nigerian economy is still being held hostage by the oil industry, which has not only brought benefits to the country, because it has also contributed significantly to end most of the traditional means of subsistence in that Delta, such as agriculture and fishing. Pollution caused by oil exploration has been gradually contaminating the land due to the deposit of a large amount of hazardous waste, which has led to the abandonment of many agricultural lands, thus increasing even more the subsistence difficulties on the part of the population. The latter is also no longer able to rely on fishing in a large part of its lakes and rivers, as pollution has caused a lack of oxygen in the waters and, consequently, a decrease in the number of fish and an increase in water-borne diseases.

On the other hand, the rapid demographic growth that has been felt in Nigeria, where about $62.3 \%{ }^{10}$ of the population, in other words, 126679957 of Nigerians, less than 25 years old, have undoubtedly been instrumental in justifying the number of young Nigerians who have been associated with maritime piracy / ARAS.

If the situation on the ground is unstable, either in Nigeria or in practically all other GG States, at sea, illicit activity in general and maritime piracy / ARAS in particular have plagued the region a lot in recent years. In the period between 2000 and 2018, inclusive, according to IMB records ${ }^{11}$, an average of 38 acts of maritime piracy / ARAS per year occurred in this Gulf, with the waters of Nigeria being considered the most dangerous, with an average of 25 acts per year, in the same period of time.

8 Angola, Belgium, Benin, Brazil, Cape Verde, Cameroon, Canada, Ivory Coast, Democratic Republic of Congo, Denmark, France, Gabon, Gambia, Germany, Ghana, Guinea, Guinea-Bissau, Equatorial Guinea, Liberia, Morocco, Namibia , Netherlands, Nigeria, Portugal, Republic of Congo, São Tomé and Príncipe, Senegal, Sierra Leone, Spain, Togo, Turkey and the United States.

9 Includes the states of Cross River, Akwa Ibom, Rivers, Bayelsa, Delta and Edo.

10 The World Factbook.

11 IMB - International Maritime Bureau. 
Figure 1 - Maritime piracy / ARAS acts in the GG between 2000 and 2018

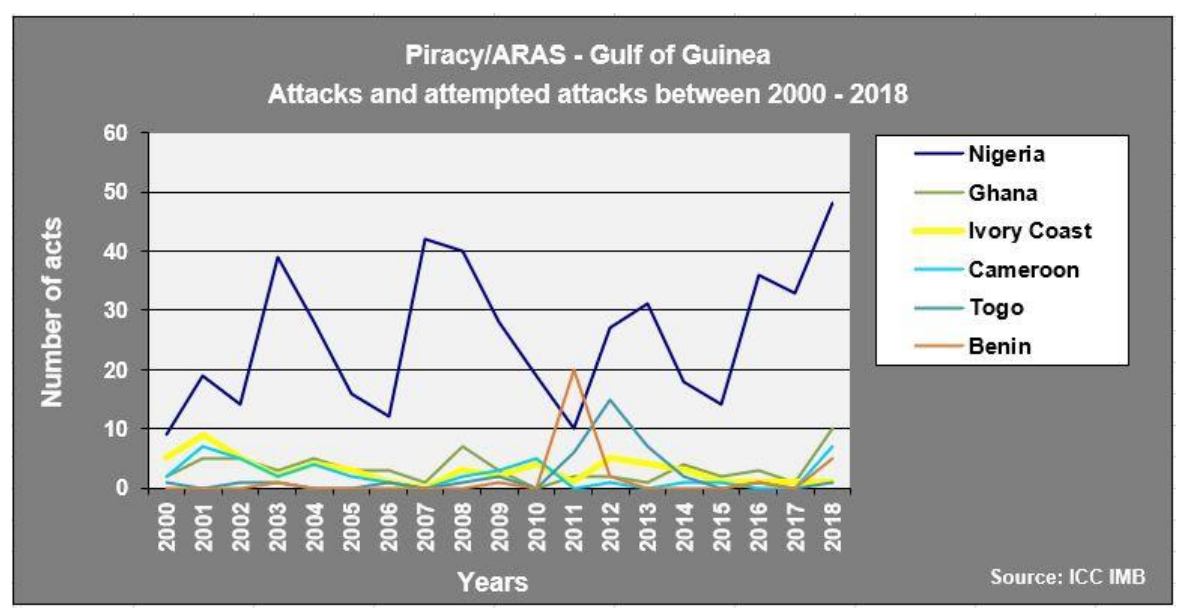

In 2018 alone, there were 72 acts of maritime piracy / ARAS in this Gulf, of which 48 in Nigeria, which makes this year the worst ever in terms of this phenomenon in the last 28 years $^{12}$, either in this Gulf or in Nigeria.

Figure 2 - Acts of maritime piracy / ARAS at GG in 2018

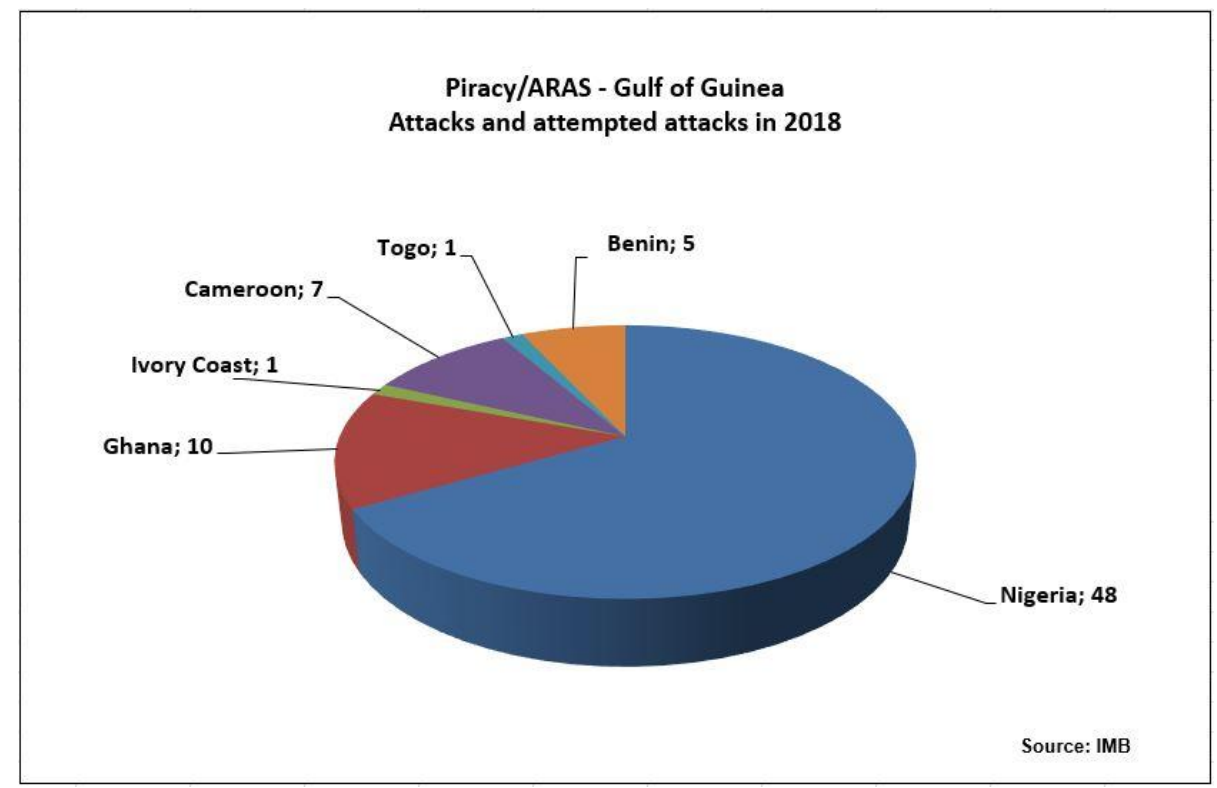

The previous highs had been 54 acts in 2008 and 42 acts in 2007, respectively in GG and Nigeria. It is said that, in the case of Nigeria, the number of reported acts may not even reach $50 \%$ of those that have actually occurred.

Despite the figures showing the contrary, since 2015 there has been an improvement in patrolling by the Nigerian Navy, which, together with the lowering of crude prices, has

12 IMB registers the number of acts of maritime piracy / ARAS worldwide since 1991. 
caused the pirates' Modus Operandi to change. Right now, there are practically no hijackings of ships for theft of crude (Bunkering) and subsequent sale on the black market, which had been a common practice in recent years. An act of Bunkering can take one or more days to consummate, with the strong possibility that the pirates are discovered and arrested by the authorities. On the other hand, the number of attacks with the purpose of kidnapping crew members of the ships has been increasing, with a view to obtaining high amounts for their rescue. This is the current Modus Operandi of the pirates. Their dexterity is already such that they are able to consummate their acts in relatively short periods of time, sometimes around 30 minutes, which allows them to have a very high success rate in their actions. Due to the fact that the activity of pirates in this Gulf is now very much directed towards the kidnapping of seafarers, to obtain ransoms, the number of kidnapped crew members has been increasing significantly in recent times, and the situation is expected to worsen in the near future.

\section{Conclusions}

Although the GG region is very rich in natural resources, the impoverishment of populations, corruption, anarchy and social dislocation are common to virtually all countries in this Gulf. These are the factors that, associated with the great proliferation of illegal weapons and the proximity of major trade routes, have encouraged the resurgence of maritime piracy / ARAS in the region.

In Nigeria, the country where most of the pirates working in the GG come from, the interethnic tensions caused by the social instability that exists in that country, have generated a lot of violence between armed groups and between them and the government, especially in the various states of the Niger River Delta. Some of these groups started to dedicate themselves to maritime piracy / ARAS as a way to get "easy" money, because they see this activity as profitable and not very dangerous, which allows them not only to finance their activities, but sometimes their livelihood and that of their families.

Since sea piracy / ARAS can never be eradicated from the seas, government efforts should be made to minimize it, therefore, it is necessary for the GG countries to adopt social development measures that provide better living conditions, job creation and promote literacy and social justice. In the particular case of Nigeria, the large amounts obtained from the sale of oil should first be used in the areas from which it is extracted, giving more well-being to local populations.

The fight against maritime piracy / ARAS in GG, to be more effective, must involve everyone, which will only be achieved with greater awareness of the importance of maritime security, either by governments or local populations. The national, regional and global interests of the countries are increasingly passing through the sea - in areas such as trade, maritime transport, fishing, tourism and the exploitation of marine resources, among many other activities -, whose success will only be possible with maritime piracy / ARAS reduced to a minimum, since it will never be possible to eradicate it once and for all. 


\section{References}

\section{Books}

Guedes, Henrique, 2014. The World of Maritime Piracy: the last two decades. 1st Ed. Lisbon: Edições Revista de Marinha. ISBN 978-972-96535-4-4.

Payne, John C., 2010. Piracy Today - Fighting Villainy on the High Seas. 1st Ed. New York - USA: Sheridan House Inc. ISBN 978-1-57409-291-2.

Lehr, Peter, 2007. Violence at Sea: Piracy in the age of global terrorism. 1st Ed. New York - USA: Taylor \& Francis Group, LLC. ISBN 0-415-95320-0.

\section{Repports}

International Maritime Bureau, 2019. Piracy and Armed Robbery Against Ships, Annual Report 2018, United Kingdom: ICC

The Economist. Democracy Index 2018: Me too?, The Economist Intelligence Unit Limited 2019

United Nations Development Programme (UNDP). Human Development Indices and Indicators: 2018 Statistical Update, 1 UN Plaza, New York, NY 10017 USA

\section{Online electronic sources}

International Maritime Bureau. Available at: http://www.icc-ccs.org [Accessed March 15, 2019].

RINKEL, Serge - Piracy and Maritime Crime in the Gulf of Guinea: Experience-based Analyses of the Situation and Policy Recommendations. Available at: https://www.ispk.uni-kiel.de/de/publikationen/arbeitspapiere/serge-rinkel-piracy-andmaritime-crime-in-the-gulf-of-guinea-experience-based-analyses-of-the-situation-andpolicy-recommendations [Accessed on March 10, 2019].

The World Factbook. Disponível em: https://www.cia.gov/library/publications/the-worldfactbook/geos/ni.html [Accessed on March 5, 2019].

Transparency International. Disponível em: www.transparency.org [Accessed on March 5, 2019].

\section{Conventions}

United Nations Convention on the Law of the Sea (UNCLOS), December 10, 1982.

\section{UNSC Resolutions}

United Nations Security Council Resolution No. 2018 (2011), adopted at its meeting No. 6645, of 31 October 2011.

United Nations Security Council Resolution No. 2039 (2012), adopted at its meeting No. 6727, of 29 February 2012. 
JANUS.NET, e-journal of International Relations e-ISSN: $1647-7251$

Vol. 11, No. 1 (May-October 2020), pp.112-119 Maritime piracy in the Gulf of Guinea Henrique Portela Guedes

\section{How to cite this note}

Guedes, Henrique Portela (2020). "Maritime piracy in the Gulf of Guinea". JANUS.NET ejournal of International Relations, Vol. 11, N.O 1, May-October 2020. Consulted [online] on the date of the last visit, https://doi.org/10.26619/1647-7251.11.1.01

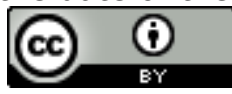

